УДК 347.998.85

DOI https://doi.org/10.32837/pyuv.v2i3(28).350

\author{
А. В. Басалаєва \\ orcid.org/0000-0001-7558-2621 \\ аспірант кафедри адміністративного права \\ Київського національного університету ілені Тараса Шевченка
}

\title{
МІСЦЕВІ СУДИ ЯК СУБ'СКТИ МЕХАНІЗМУ ЗАХИСТУ ВИБОРЧИХ ПРАВ
}

Постановка проблеми. 3 огляду на положення статті 6 Конвенції про захист прав людини та основоположних свобод кожному має гарантуватися забезпечення реалізації його законних прав та свобод людини встановленим національним законодавством судом, який визначається як найбільш ефективний спосіб її гарантування. Отже, основним міжнародним стандартом забезпечення захисту прав і свобод людини є необхідність встановлення лише нормами чинного національного законодавства України вимоги щодо визначення сутності та критеріїв предметної юрисдикції судів щодо розгляду та вирішення приватно-правових та публічно-правових спорів.

Прийняття у 2005 році Кодексу адміністративного судочинства України докорінно змінило розуміння системи судового захисту прав і свобод людини. Так, відповідно до п. 6 ч. 1 ст. 19 Кодексу адміністративного судочинства України, встановлено, що саме до предметної юрисдикції місцевих судів належать розгляд та врегулювання спорів, що виникають під час реалізації виборчого процесу.

Стан наукової розробки проблеми. Варто відзначити, що з'ясуванню ролі та значення місцевих судів у врегулюванні виборчих спорів присвячено наукові публікації таких вчених, як В.М. Бевзенко [1], А.Т. Комзюк, Р.С. Мельник [2; 3], С.В. Ківалов [4], Р.О. Куйбіда, О.М. Пасенюк [5], M.I. Смокович [6; 7; 8] та інші.

Отже, встановлення місця місцевих судів загальної юрисдикції у системі захисту виборчих прав є одним з головних питань забезпечення ефективності захисту прав і свобод людини загалом, що і визначило мету нашого дослідження.

Виклад основного матеріалу. Відповідно до пункту 6 ч. 1. ст. 19 Кодексу адміністративного судочинства України юрисдикція адміністративних судів поширюється на спори щодо правовідносин, пов'язаних з виборчим процесом чи процесом референдуму.

Місцевим судам як адміністративним судам підсудні адміністративні справи, пов'язані з виборчим процесом чи процесом референдуму, щодо: оскарження рішень, дій чи бездіяльності дільничних виборчих комісій, дільничних комісій з референдуму, членів цих комісій; уточнення списку виборців; оскарження дій чи бездіяльності засобів масової інформації, інформаційних агентств, під- приємств, установ, організацій, їх посадових та службових осіб, творчих працівників засобів масової інформації та інформаційних агентств, що порушують законодавство про вибори та референдум; оскарження дій чи бездіяльності кандидата у депутати сільської, селищної ради, кандидатів на посаду сільського, селищного голови, їх довірених осіб (п. 2 ч. 1 ст. 20 КАС України).

Запровадження до системи адміністративних судів загальних місцевих судів зумовлено необхідністю забезпечення реалізації принципу оперативного врегулювання найбільш розповсюджених різновидів виборчих спорів, зокрема спорів, пов'язаних із уточненням списків виборців.

Розмежування предметної юрисдикції адміністративних судів, місцевих загальних судів як адміністративних та окружних адміністративних судів визначено достатньо чітко на законодавчому рівні. Крім того, місцеві загальні суди уповноважені розглядати справи щодо застосування заходів адміністративної відповідальності за порушення норм виборчого законодавства, передбачені ст. 212-7-212-21 Кодексу України про адміністративні правопорушення (ч. 1 ст. 221 Кодексу України про адміністративні правопорушення).

Віднесення до предметної юрисдикції загальних місцевих судів розгляду та вирішення окремих категорій виборчих спорів (оскарження рішень, дій чи бездіяльності дільничних виборчих комісій, дільничних комісій з референдуму, членів цих комісій; уточнення списку виборців; оскарження дій чи бездіяльності засобів масової інформації, інформаційних агентств, підприємств, установ, організацій, їх посадових та службових осіб, творчих працівників засобів масової інформації та інформаційних агентств, що порушують законодавство про вибори та референдум; оскарження дій чи бездіяльності кандидата у депутати сільської, селищної ради, кандидатів на посаду сільського, селищного голови, їх довірених осіб) з огляду на їх більшу розгалуженість свідчить про прагнення законодавця зробити доступним правосуддя. Віднесення до предметної юрисдикції загальних місцевих судів таких виборчих спорів у своїй основі має застосування змістовного критерію визначення приналежності спору до визначення кола суб’єктів, уповноважених на їх врегулювання. Характеристика публічно-пра- 
вових спорів, пов'язаних з оскарженням дій чи бездіяльності засобів масової інформації, інформаційних агентств, підприємств, установ, організацій, їх посадових та службових осіб, творчих працівників засобів масової інформації та інформаційних агентств, що порушують законодавство про вибори та референдум, також грунтується на встановленні факту їх виникнення під час проведення виборчого процесу, в інших випадках такі спори розглядаються та вирішуються адміністративними судами.

Віднесення до предметної юрисдикції загальних місцевих судів розгляду та вирішення спорів, пов'язаних із оскарженням дій чи бездіяльності кандидата у депутати сільської, селищної ради, кандидатів на посаду сільського, селищного голови, їх довірених осіб, є підтвердженням прагнення законодавця забезпечити доступ до правосуддя під час проведення місцевих виборів, що сприяє оперативному врегулюванню таких суперечностей.

У зазначених категоріях публічно-правових спорів характерною ознакою $є$ їх виникнення та розвиток під час виборчого процесу.

Наділення місцевих загальних судів повноваженнями щодо розгляду та вирішення окремих категорій публічно-правових спорів означає, що такі спори розглядаються за процедурою адміністративного судочинства.

Відповідно до ст. 274 КАС України встановлюються процедурні особливості розгляду та вирішення спорів, пов'язаних із уточненням списків виборців.

Право звернутися з адміністративним позовом про уточнення списку виборців, у тому числі про включення або виключення зі списку себе особисто або інших осіб, має кожен, хто має право голосу на відповідних виборах або референдумі. Адміністративні справи щодо уточнення списку виборців розглядає місцевий загальний суд як адміністративний суд за місцезнаходженням відповідної комісії (ст. 274 КАС України).

В Україні діє Державний реєстр виборців, уповноваженим розпорядником якого $€$ Центральна виборча комісія України [10], доступ до якого у 2019 році було суттєво спрощено шляхом створення можливостей до його реалізації в електронній формі. Завданнями створення Державного реєстру виборців $€$ : «1) ведення персоніфікованого обліку виборців; 2) складання списків виборців для проведення виборів Президента України, народних депутатів України, депутатів Верховної Ради Автономної Республіки Крим, місцевих рад, сільських, селищних, міських голів, всеукраїнських та місцевих референдумів" (ст. 2 Закону України «Про Державний реєстр виборців») [10].

Дані Державного реєстру виборців України є основою для формування попередніх списків виборців на звичайних виборчих дільницях (ст. 39 Виборчого кодексу України) [11]. Відповідно до ч. 1 ст. 41 Виборчого кодексу України не пізніше як за тринадцять днів до дня голосування орган ведення Державного реєстру виборців передає попередній список виборців на паперовому носії та виготовлені іменні запрошення відповідній дільничній виборчій комісії (в особі комісії, що складається із не менше ніж трьох членів). До списків виборців мають бути «включені громадяни України, яким виповнилося або на день голосування на виборах виповниться 18 років і які мають право голосу на відповідних вибоpax та належать до цієї виборчої дільниці згідно з відомостями Державного реєстру виборців» (ч. 2 ст. 39 Виборчого кодексу України). Виборець може бути включений до списку виборців тільки на одній виборчій дільниці [11].

Попередні виборчі списки формуються на підставі визначення виборчої адреси особи, яка має право голосу на відповідних виборах. Відповідно до ч. 2 ст. 8 Закону України «Про Державний реєстр виборців» виборчою адресою виборця є адреса, за якою зареєстровано його місце проживання відповідно до Закону України «Про свободу пересування та вільний вибір місця проживання в Україні» [12].

Світова практика складання списків виборців свідчить про доцільність виокремлення критеріїв їх обов'язковості як критеріїв дотримання законності виборчого процесу. В Україні складання списків виборців належить до обов'язку суб'єктів публічного управління, їх відсутність, неточності під час складання є підставою для застосування заходів адміністративної відповідальності до відповідних посадових осіб [13, с. 64]. Якщо складання списку виборців не є обов'язком органу державної влади, то такий обов'язок покладається безпосередньо на особу, яка має право голосу на відповідних виборах, і відтак застосування заходів відповідальності за невнесення особи до списку виборців $є$ можливим лише у разі ініціативності її поведінки [13, с. 64].

Порівняно з попередньою редакцією Кодексу адміністративного судочинства України, було скорочено термін розгляду та вирішення спорів, пов'язаних із уточненням виборчих списків із п'ятиденного терміну (ч. 1 ст. $173 \mathrm{KAC} \mathrm{України)}$ до дводенного (ч. 4 ст. 274 КАС України), що обчислюється з моменту надходження до суду позовної заяви, але не пізніше ніж за два дні до голосування. Вирішення такого спору передбачає з боку загальних місцевих судів вчинення дій, спрямованих на визначення обгрунтування шляхом направлення офіційного запиту до розпорядника публічних даних Державного реєстру виборців, відповідь на який $є$ підставою до внесення змін до попереднього списку виборців, що має бути вчинено не пізніше, ніж за два дні до голосування, уповноваженим суб'єктом виборчого процесу 
(знову ж таки термін вирішення такої категорії спорів порівняно з попередньою редакцією КАС України було переглянуто у бік збільшення, що сприяе врешті-решт належному захисту виборчих прав та інтересів). Рішення суду про внесення змін до списку виборців підлягає негайному виконанню дільничною виборчою комісією.

О.Ю. Піддубний, досліджуючи проблеми розгляду та вирішення публічно-правових спорів, пов'язаних із уточненням списків виборців, обгрунтовує доцільність визнання як належного відповідача у такій категорії справ відповідну дільничну виборчу комісію, при цьому територіальний орган ведення Державного реєстру виборців може залучатися до розгляду справи як третя особа, що не заявляє самостійних вимог [14, с. 210].

Позивач у справах про уточнення списку виборців звільняється від сплати судового збору, що пов'язується передусім $з$ необхідністю оперативного врегулювання наявних технічних чи інших помилок, зі значною кількістю таких спорів, із передбачуваним результатом розгляду таких спорів, а також із необхідністю забезпечення принципу рівності реалізації наданих конституційних виборчих прав [14, с. 211].

Розгляд спорів, пов'язаних із уточненням списку виборців, здійснюється місцевими судами у загальному порядку. Таким, що не порушує права суб'єктів спору, є розгляд судом справи по суті, у разі їх неприбуття у судове засідання, за умови дотримання вимог належності повідомлення про дату, час і місце розгляду справи [15, с. 428]. Повідомлення про час, дату та місце розгляду справи має бути здійснено у будь-якій допустимій формі, в тому числі в електронній формі.

Належне виконання рішення суду у справах про уточнення списку виборців залежить від якості викладення iï резолютивної частини, де має бути чітко передбачено, які саме дії має вчинити уповноважений суб'єкт виборчого процесу (наприклад, внести позивача до списку виборців, внести виправлення у списки виборців щодо персональних даних позивача, виключити особу, яка була включена туди неправомірно, зі списку виборців тощо).

Необхідно наголосити, що реалізація права особи чи політичної партії як суб'єкта публічного контролю за дотриманням принципу верховенства права під час організації проведення виборчого процесу шляхом звернення до відповідного регіонального органу адміністрування Державного реєстру виборців з питань оскарження рішення, дії чи бездіяльності органу ведення такого реєстру у адміністративному порядку передбачає подальший розгляд таких спорів у порядку адміністративного судочинства відповідним адміністративним судом, адже в таких спорах оспорюється саме інформаційне забезпечення ведення Державного реєстру виборців, а не складання окремих списків виборців чи їх уточнення (ст.ст. 31, 32 Закону України «Про Державний реєстр виборців»).

Згідно з експертними оцінками результатів розгляду масиву спорів, пов'язаних з уточненням списків виборців, необхідно відзначити належний рівень якості судових рішень, що відповідає таким критеріям, як правильність вирішення питань територіальної та предметної підсудності спорів, правильність встановлення суб’єктів розгляду (прийнятність скарг та належність учасників), дотримання процесуальних строків, повнота дослідження доказів, наявних у справі (наведених сторонами), простота та доступність стилю, відсутність надмірності у викладі обставин справи, чіткість формулювання предмету спору (в обсязі, достатньому для розуміння змісту спору), можливість розуміння позиції та висновків суду особою, що програла справу та планує оскарження, тоді як найнижчі експертні оцінки надані таким критеріям якості рішень суду, як дотримання єдності судової практики (правової позиції вищих судів), повнота застосування законодавства (використано всі належні нормативно-правові акти) та правильність оцінки юридично значущих обставин справи (їх повнота, достатність, доведеність) [16, с. 18-19]. Зокрема, неприпустимим і таким, що свідчить про низьку якість рішення суду, є викладення його мотивувальної частини із посиланням лише на норми Конституції України чи іншого одного нормативно-правового акту [16, с. 22].

На нашу думку, причиною низької якості рішень місцевих судів загальної юрисдикції щодо врегулювання віднесених до їх предметної юрисдикції виборчих спорів є надмірно формалізований підхід до вирішення відповідної категорії спорів, що подекуди своїм результатом має суперечність вимоги дотримання верховенства права як пріоритетного регулятора будь-якої групи суспільних правовідносин, в тому числі тих, що виникають під час виборчого процесу. Зокрема, судами застосовується формалізований підхід щодо здійснення тлумачення актів чинного законодавства України (особливо процесуальних норм) без урахування специфіки сутності виборчих спорів. Прикладами такого формалізованого підходу є, зокрема, рішення Білгород-Дністровського міськрайонного суду Одеської області у справі №495/7689/15-а, рішення Миколаївського окружного адміністративного Суду у справі № 814/3920/15, сутність яких зводиться до визнання правомірності надмірної реєстрації виборців за декількома виборчими адресами, що напередодні дня голосування є загрозою до проведення виборів на засадах вільного та рівного волевиявлення. Зокрема, аргументація позивача зводилася до того, що реєстрація значної кількості осіб за однією виборчою адре- 
сою, створює реальні загрози забезпеченню проведення вільних та рівних місцевих виборів.

Вбачається, що зменшенню кількості публічно-правових спорів, пов'язаних із уточненням списку виборців, сприятиме запровадження системи електронного голосування.

Висновки. Отже, варто підкреслити, що попри переслідування «благих" цілей, які вирішуються через надання окремих повноважень місцевим загальним судам із розгляду та вирішення окремих різновидів виборчих спорів, є очевидні негативні наслідки такого законодавчого врегулювання цієї групи правовідносин. Передусім таким чином нівелюється унікальна природа адміністративної юстиції як спеціалізованої системи судів, діяльність яких є важелем системи «стримувань та противаг» у механізмі публічного управління. Крім того, попри вирішення задачі «розвантаження» адміністративних судів, виникає інша проблема необхідність застосування чотирьох процедурних форм врегулювання правових спорів, що покладається на загальні місцеві суди. Судді загальних місцевих судів «змушені» розглядати справи у порядку цивільного, кримінально-процесуального судочинства, вирішувати окремі категорії публічно-правових спорів у порядку адміністративного судочинства та розглядати справи про застосування заходів адміністративної відповідальності, що створюе надзвичайно складні умови для реалізації принципу спеціалізації у їх професійній діяльності, а отже, негативно впливає на рівні ефективності та якості їх правозахисної діяльності.

Загалом необхідно відзначити, що віднесення до предметної юрисдикції загальних місцевих судів окремих категорій виборчих спорів має бути визнано вимушеним заходом, застосування якого в сучасних реаліях сприяє вирішенню проблеми доступу до правосуддя на засадах оперативності та рівності. Однак надалі необхідно відмовитися від такого «вимушеного» заходу шляхом поступового запровадження системи електронного голосування та доступу до електронного реєстру виборців України. Запровадження та ефективне використання електронного реєстру виборців (Державного реєстру виборців України) не лише сприятиме вирішенню проблеми збереження унікальної предметної спеціалізації адміністративних судів, а і вирішіть проблему голосування «мертвих душ», що врешті-решт є базисом для створення дієвої системи публічного управління, що формується на засадах прозорості, відкритості та всебічного громадського контролю.

Таким чином, ефективність здійснення судового контролю загальними місцевими судами залежить від розуміння необхідності відповідності ix рішень вимогам верховенства права та недоцільності надмірного формалізованого підходу до розгляду та вирішення виборчих спорів, що вимагає врахування їх специфіки. Надалі перспективним напрямом розвитку системи судового захисту виборчих прав громадян має стати підвищення якості формування складу виборчих комісій, підвищення якості реалізації процедури адміністративного оскарження та впровадження ідеї електронного голосування, що у своїй сукупності сприятиме виключенню загальних місцевих судів із системи судового захисту виборчих прав громадян.

\section{Jimepamypa}

1. Бевзенко В.М. Адміністративні суди України : навчальний посібник. Київ : Алерта ; КНТ, 2006. 271 с.

2. Адміністративний процес України : навчальний посібник. Київ : Прецедент, 2007. 531 с.

3. 100 ответов на 100 вопросов по Общему административному праву : учеб. пособ. / под ред. Р. С. Мельника. Киев : Юринком Интер, 2017. 240 с.

4. Ківалов С.В. Право на звернення до адміністративного суду з адміністративним позовом: проблеми теорії і правового регулювання. Актуальні проблеми держави і права : зб. наук. праць. Одеса : НУ ОЮА, 2011. Вип. 59. С. 7-21.

5. Адміністративна юстиція: європейський досвід і пропозиції для України / авт.-упоряд.: І. Б. Коліушко, Р.О. Куйбіда. Київ : Факт, 2003. 536 с.

6. Смокович М. Вибори як інститут забезпечення демократії в Україні Юридична Україна. 2014. № 11. C. $37-45$.

7. Смокович М. Сторони виборчого спору щодо виборів народних депутатів: проблеми визначення. Юридична Україна. 2012. № 8. С. 43-50.

8. Смокович M.I. Правове регулювання розгляду виборчих спорів : теоретичний та практичний аспекти : монографія. Київ : Юрінком Інтер, 2014. 576 с.

9. Смокович М. Сторони виборчого спору щодо виборів народних депутатів: проблеми визначення. Юридична Україна. 2012. № 8. С. 43-50.

10. Про Державний реєстр виборців : Закон України від 22 лютого 2007 року № 698-V. Відомості Верховної Ради України. 2007. № 20. Ст.282.

11. Виборчий кодекс України : Закон України від 19 грудня 2019 року № 396-IX. Офіиійний вісник України. 2020. № 4. Том 1. Ст. 188.

12. Постанова Деснянського районного суду міста Києва від 29 березня 2019 року у справі №754/4755/19. URL: http://www.reyestr.court.gov. ua/Review/80814311.

13. М'яловицька Н.В. Виборчі системи європейських держав. Вісник Центральної виборчої комісії. 2008. № 1. С. 61-67.

14. Піддубний О.Ю. Окремі аспекти уточнення списків виборців у судовому порядку. Науковий вісник Національного університету біоресурсів і природокористування України. 2014. Вип. 197. Ч. 3. С. 208-214.

15. Кодекс адміністративного судочинства України : наук.-практ. комент. Харків, 2008. 648 с.

16. Виборчі спори : експертна оцінка якості судових рішень (місцеві вибори 2015 року) Аналітичний звіт. Проект USAID «Справедливе правосуддя»; ХМГО «Інститут прикладних гуманітарних досліджень»: Т. Калмиков, В. Кохан, О. Сердюк, М. Буроменський, С.Кальченко, Ф. Веніславський. Харків, ІПГД. $2016.58 \mathrm{c}$. 


\begin{abstract}
Анотація
Басалаєва А. В. Місцеві суди як суб'єкти механізму захисту виборчих прав. - Стаття.

У статті автором визначено роль та значення місцевих судів у системі врегулювання виборчих спорів в Україні. Автором визначено, що попри переслідування «благих» цілей, які вирішуються через надання окремих повноважень місцевим загальним судам із розгляду та вирішення окремих різновидів виборчих спорів, очевидними негативними наслідками такого законодавчого врегулювання цієї групи правовідносин $€$ нівелювання унікальної природи адміністративної юстиції як спеціалізованої системи судів, діяльність яких є важелем системи "стримувань та противаг» у механізмі публічного управління. До проблем функціонування загальних місцевих судів у системі розгляду та вирішення виборчих спорів віднесено необхідність застосування чотирьох процедурних форм врегулювання правових спорів, що на них покладаються. Автором зазначено, що судді загальних місцевих судів «змушені» розглядати справи у порядку цивільного, кримінально-процесуального судочинства, вирішувати окремі категорії публічно-правових спорів у порядку адміністративного судочинства та розглядати справи про застосування заходів адміністративної відповідальності, що створює надзвичайно складні умови для реалізації принципу спеціалізації у їх професійній діяльності, а отже, негативно впливає на рівні ефективності та якості їх правозахисної діяльності. Автором підкреслено, що віднесення до предметної юрисдикції загальних місцевих судів окремих категорій виборчих спорів має бути визнано вимушеним заходом, застосування якого в сучасних реаліях сприяе вирішенню проблеми доступу до правосуддя на засадах оперативності та рівності. Автором зроблено висновок, що надалі необхідно відмовитися від такого «вимушеного» заходу шляхом поступового запровадження системи електронного голосування та доступу до електронного реєстру виборців України. Автором підкреслено, що запровадження та ефективне використання електронного реєстру виборців (Державного реєстру виборців України) сприяє не лише вирішенню проблеми збереження унікальної предметної спеціалізації адміністративних судів, а і вирішіть проблему голосування «мертвих душ», що врешті-решт є базисом для створення дієвої системи публічного управління, що формується на засадах прозорості, відкритості та всебічного громадського контролю. Автором зроблено висновок, що ефективність здійснення судового контролю загальними місцевими судами залежить від розуміння необхідності відповідності їх рішень вимогам верховенства права та недоцільності надмірного формалізованого підходу до розгляду та вирішення виборчих спорів, що вимагає врахування їх специфіки.
\end{abstract}

Ключові слова: виборець, електронне голосування, провадження, реєстр, судовий контроль, юрисдикція.

\section{Summary}

Basalaieva $A$. $V$. Local courts as subjects of the voting rights mechanism. - Article.

In the scientific article the author defined the role and importance of local courts in the system of electoral dispute settlement in Ukraine. The author determined that despite the pursuit of "good" goals, which are solved by granting certain powers to the local general courts to consider and resolve certain types of electoral disputes, the obvious negative consequences of such a legislative settlement of this legal relationship are the neutralization of the unique nature of the administrative justice system as a specialty which are the leverage of the system of checks and balances in the mechanism of public administration. The problems of the functioning of the general local courts in the system of consideration and settlement of electoral disputes include the need to apply the four procedural forms of settlement of legal disputes, which they rely on. The author points out that judges of the general local courts are "compelled" to hear cases in civil, criminal procedure, to resolve certain categories of public law disputes in the procedure of administrative justice, and to consider cases of application of administrative liability measures, which creates extremely difficult conditions for implementation specialization in their professional activity, and therefore - negatively affects the level of efficiency and quality of their human rights activities. The author emphasized that the classification of particular categories of electoral disputes in the general jurisdiction of the general local courts should be recognized as a compulsory measure, the application of which in modern realities contributes to the solution of the problem of access to justice on the basis of efficiency and equality. The author concludes that in the future it is necessary to abandon such "forced" measure as is seen through the gradual introduction of the electronic voting system and access to the electronic register of voters of Ukraine. The author emphasizes that the introduction and effective use of the electronic voter register (the State Register of Voters of Ukraine) not only solves the problem of preserving the unique subject specialization of administrative courts, but also solves the problem of voting "dead souls", which in the end is the basis for creating an effective public system governance based on transparency, openness and comprehensive public scrutiny. The author concludes that the effectiveness of judicial review by general local courts depends on understanding the need for compliance of their decisions with the requirements of the rule of law and the inappropriateness of an overly formalized approach to the consideration and resolution of electoral disputes, which requires consideration of their specificity.

Key words: voter, electronic voting, proceedings, register, judicial review, jurisdiction. 